\title{
Good science for improving policy: greenhouse gas emissions from agricultural manures
}

\author{
Chris Pratt ${ }^{\mathrm{A}, \mathrm{C}}$, Matthew Redding ${ }^{\mathrm{A}}$, Jaye Hill ${ }^{\mathrm{A}}$, Andrew Shilton ${ }^{\mathrm{B}}$, Matthew Chung ${ }^{\mathrm{B}}$ \\ and Benoit Guieysse ${ }^{\mathrm{B}}$

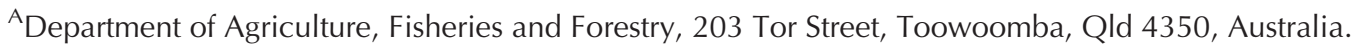 \\ ${ }^{B}$ School of Engineering, Massey University, Palmerston North 4472, New Zealand. \\ ${ }^{\mathrm{C} C}$ orresponding author. Email: christopher.pratt@daff.qld.gov.au
}

\begin{abstract}
Australia's and New Zealand's major agricultural manure management emission sources are reported to be, in descending order of magnitude: (1) methane $\left(\mathrm{CH}_{4}\right)$ from dairy farms in both countries; (2) $\mathrm{CH}_{4}$ from pig farms in Australia; and nitrous oxide $\left(\mathrm{N}_{2} \mathrm{O}\right)$ from (3) beef feedlots and (4) poultry sheds in Australia. We used literature to critically review these inventory estimates. Alarmingly for dairy farm $\mathrm{CH}_{4}(1)$, our review revealed assumptions and omissions that when addressed could dramatically increase this emission estimate. The estimate of $\mathrm{CH}_{4}$ from Australian pig farms (2) appears to be accurate, according to industry data and field measurements. The $\mathrm{N}_{2} \mathrm{O}$ emission estimates for beef feedlots (3) and poultry sheds (4) are based on northern hemisphere default factors whose appropriateness for Australia is questionable and unverified. Therefore, most of Australasia's key livestock manure management greenhouse gas (GHG) emission profiles are either questionable or are unsubstantiated by region-specific research. Encouragingly, GHG from dairy shed manure are relatively easy to mitigate because they are a point source which can be managed by several 'close-to-market' abatement solutions. Reducing these manure emissions therefore constitutes an opportunity for meaningful action sooner compared with the more difficult-to-implement and long-term strategies that currently dominate agricultural GHG mitigation research. At an international level, our review highlights the critical need to carefully reassess GHG emission profiles, particularly if such assessments have not been made since the compilation of original inventories. Failure to act in this regard presents the very real risk of missing the 'low hanging fruit' in the rush towards a meaningful response to climate change.
\end{abstract}

Additional keywords: manure management, methane, mitigation, nitrous oxide.

Received 25 November 2013, accepted 7 May 2014, published online 1 September 2014

\section{Introduction}

Agriculture represents $5-15 \%$ of Australia's and $60 \%$ of New Zealand's (NZ) export revenues (New Zealand Government 2013). This economic powerhouse has an unfortunate environmental downside because agriculture is also a major source of the greenhouse gases $(\mathrm{GHG})$ nitrous oxide $\left(\mathrm{N}_{2} \mathrm{O}\right)$ and methane $\left(\mathrm{CH}_{4}\right)$. There are three main sources of agricultural GHG in Australia and NZ: (1) enteric $\mathrm{CH}_{4}$, (2) soil $\mathrm{N}_{2} \mathrm{O}$ and (3) manure management $\mathrm{CH}_{4}$ and $\mathrm{N}_{2} \mathrm{O}$. Most of the agricultural emissions in these countries occur as enteric $\mathrm{CH}_{4}$ and soil $\mathrm{N}_{2} \mathrm{O}$. In $\mathrm{NZ}$, annual enteric $\mathrm{CH}_{4}$, soil $\mathrm{N}_{2} \mathrm{O}$ and manure management emissions account for $\sim 20$ mega tonnes (Mt), $10 \mathrm{Mt}$ and $1 \mathrm{Mt}$ as carbon dioxide equivalents, $\left(\mathrm{CO}_{2}-\mathrm{e}\right)$, respectively, (New Zealand Government 2013). By comparison, the annual emissions of enteric $\mathrm{CH}_{4}$, soil $\mathrm{N}_{2} \mathrm{O}$ and manure management $\mathrm{CH}_{4}$ and $\mathrm{N}_{2} \mathrm{O}$ amount to $\sim 55 \mathrm{Mt}, 12 \mathrm{Mt}$ and $4 \mathrm{Mt}$ of $\mathrm{CO}_{2}$-e, respectively, in Australia (Australian Government 2013).

The knowledge of causes, magnitude, and mitigation potential of enteric $\mathrm{CH}_{4}$ and soil $\mathrm{N}_{2} \mathrm{O}$ emissions is now well established for Australia, NZ, and overseas (de Klein et al. 2001; Dalal et al. 2003; Saggar et al. 2004; Eckard et al.
2010; Cottle et al. 2011). By contrast, agricultural manure management emission estimates have not been verified by a rigorous review of the available literature since they were developed more than 15 years ago.

A review of manure management GHG emissions in Australia and NZ is therefore needed for assessing the accuracy of the countries' GHG inventories for this category. First, it will allow for an evaluation of current inventory estimates. In NZ, Chung et al. (2013) demonstrated that $\mathrm{CH}_{4}$ emissions from dairy effluent are potentially underestimated by $400 \%$, and Hill (2012) showed that $\mathrm{CH}_{4}$ emissions from pig effluent are being overestimated by a factor of $\sim 200 \%$. These inaccuracies were caused by the inappropriate adoption of international default factors as well as the omission of key emission sources by NZ's GHG Inventory. The studies by Chung et al. (2013) and Hill (2012) revealed that a GHG emission profile within a nation's inventory can shift from minor to major, or vice versa, upon careful inspection of emission factors and management practices. A second reason a review of manure management GHG emissions is timely is because these emissions are point sources. Thus, mitigation options for these gases are more 
amenable to development and implementation than for diffuse, non-point $\mathrm{CH}_{4}$ and soil $\mathrm{N}_{2} \mathrm{O}$ emissions, which occur at the paddock-scale.

Upon critically assessing manure management GHG emission estimates in Australia and NZ it is also possible to examine whether appropriate weighting is currently given to mitigating these emissions. This is a third reason why a review of this subject is important. Hence, in this paper we evaluate (1) manure management GHG emission estimates in Australia and NZ by comparing inventory emission factors with published country-specific data, where available, (2) mitigation options for emissions from this sector focusing on barriers to and drivers for uptake and (3) whether funded research into agricultural GHG mitigation is currently balanced to achieve greatest effect.

\section{GHG emissions from key livestock sectors}

Fig. 1 shows emission profiles for Australia's and NZ's main manure management GHG sources, based on inventory data. In this review, we use Australia's and NZ's definition of 'manure management', which encompasses $\mathrm{CH}_{4}$ and direct and secondary $\mathrm{N}_{2} \mathrm{O}$ emissions from all manure management systems as well as $\mathrm{CH}_{4}$ emissions from pasture-deposited livestock manure. Global warming potentials (GWP) of 21 and 310 were used to convert $\mathrm{CH}_{4}$ and $\mathrm{N}_{2} \mathrm{O}$ emissions, respectively, to units of $\mathrm{CO}_{2}$-e. These GWP are adopted by the most recent versions (2013) of the Australian and NZ GHG inventories. In the following discussion we examine the robustness of each of the GHG profiles in Fig. 1.

\section{GHG emissions from dairy cattle 'manure management'}

According to best available estimates, $\mathrm{CH}_{4}$ emissions from NZ dairy farm anaerobic effluent ponds are the largest GHG source in NZ and Australia (Fig. 1) for the 'manure management' emission category. For example in $\mathrm{NZ} \sim 1.3$ of the $1.4 \mathrm{Mt}$ of $\mathrm{CO}_{2}$-e/year of $\mathrm{CH}_{4}$ from dairy farm manure comes from anaerobic ponds compared with just $0.1 \mathrm{Mt}$ from manure deposited on pastures [determined from data in Saggar et al. (2004)]. It is important to note that the term 'effluent pond' is used to encompass a wide range of systems from small $\left(<100 \mathrm{~m}^{3}\right)$ pits with just a few weeks' effluent storage capacity to large $\left(>2000 \mathrm{~m}^{3}\right)$ lagoons for up to 1 year's storage capacity. Both the NZ and Australian GHG inventory apply blanket definitions to their dairy effluent ponds and use the Intergovernmental Panel on Climate Change (IPCC) $\mathrm{CH}_{4}$ conversion factors developed by Mangino et al. (2001) to determine $\mathrm{CH}_{4}$ emission rates on a temperature basis. Current research being collaboratively undertaken by several NZ Government research organisations will elucidate relationships between pond design and $\mathrm{CH}_{4}$ emissions.

The input values used to determine pond $\mathrm{CH}_{4}$ emissions are shown in Table 1. This table also includes calculation parameters for all the major GHG sources discussed in this paper. Table 2 summarises the emission calculation formulae. On a liveweight basis, Chung et al.'s (2013) estimate for $\mathrm{NZ}_{\text {pond }} \mathrm{CH}_{4}$ emissions matches reasonably well with an NZ pond emission rate published by Craggs et al. (2008). These are, however, much higher than the emission rate reported by McGrath and Mason

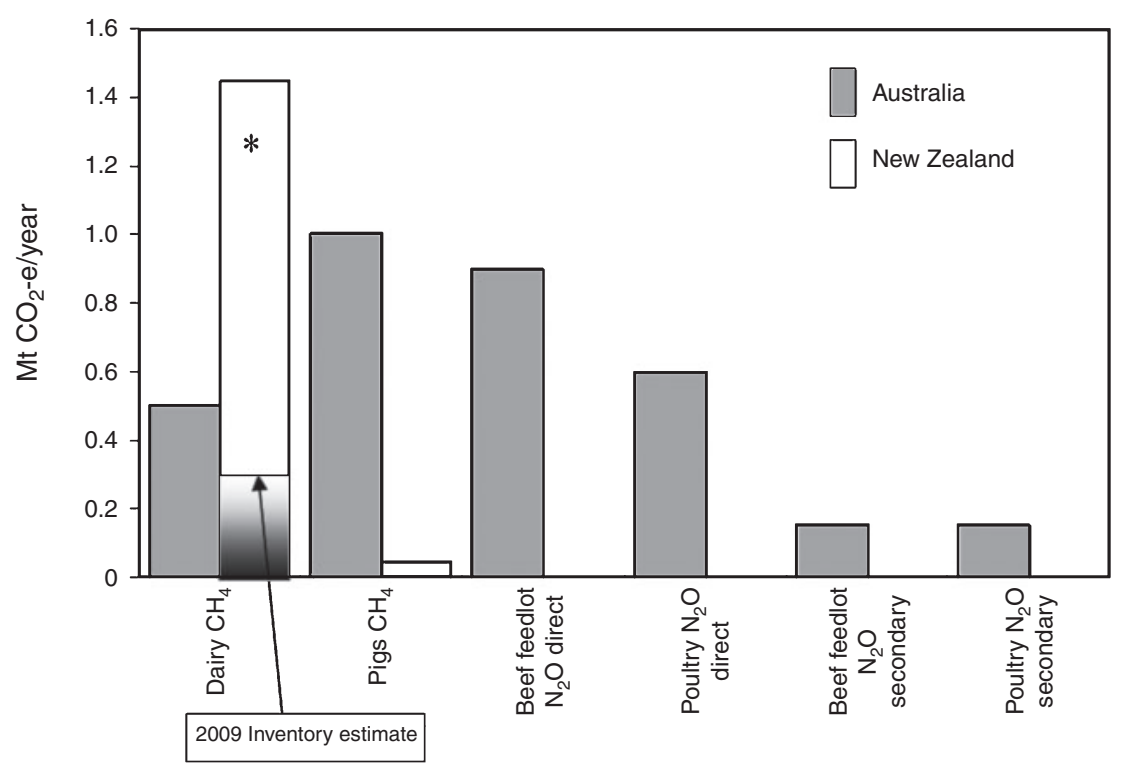

${ }^{*}$ For NZ's Dairy $\mathrm{CH}_{4}$ the main source of emissions is anaerobic effluent ponds. For these ponds, a recently published $\mathrm{CH}_{4}$ emission estimate (1.3 Mt CO - e/year) by (Chung et al., 2013) was considered more accurate than the national inventory value ( $0.3 \mathrm{Mt} \mathrm{CO}_{2}$-e/year), which contains several key mathematical errors (its input paramters are incorrect and it's affected by an erroneous geometry calculations), as well as omitting several key potential $\mathrm{CH}_{4}$ sources (such as waste feed and additional manure from feed pads). Hence, the estimate from Chung et al. (2013), which was calculated using Intergovernmental Panel on Climate Change (IPCC) methodology and NZ inputs, is included in this figure.

Fig. 1. Greenhouse gas emission profiles for major sources in the 'manure management' categories for Australia and New Zealand. The profiles are based on the most recently available inventory calendar year data (2011). New Zealand dairy methane is an exception, which was based on the publication of Chung et al. (2013). 
Table 1. Input values used to calculate emissions from the largest 'manure management' greenhouse gas sources in Australia and New Zealand $\mathrm{B}_{0}=$ biochemical methane potential, $\mathrm{MCF}=$ methane conversion factor, VS = volatile solids. References: $(1)=$ New Zealand Government $(2013)$, (2) $=$ Chung et al. (2013), (3) = IPCC (2006), (4) Ledgard and Brier (2004), (5) = Australian Government (2013), (6) = Külling et al. (2003), (7)= Rotz (2004), (8)= Hutchings et al. (2001), (9) = Bouwman et al. (2002a), (10) = Bouwman et al. (2002b), (11) = Akiyama et al. (2005), (12) = Stehfest and Bouwman (2006)

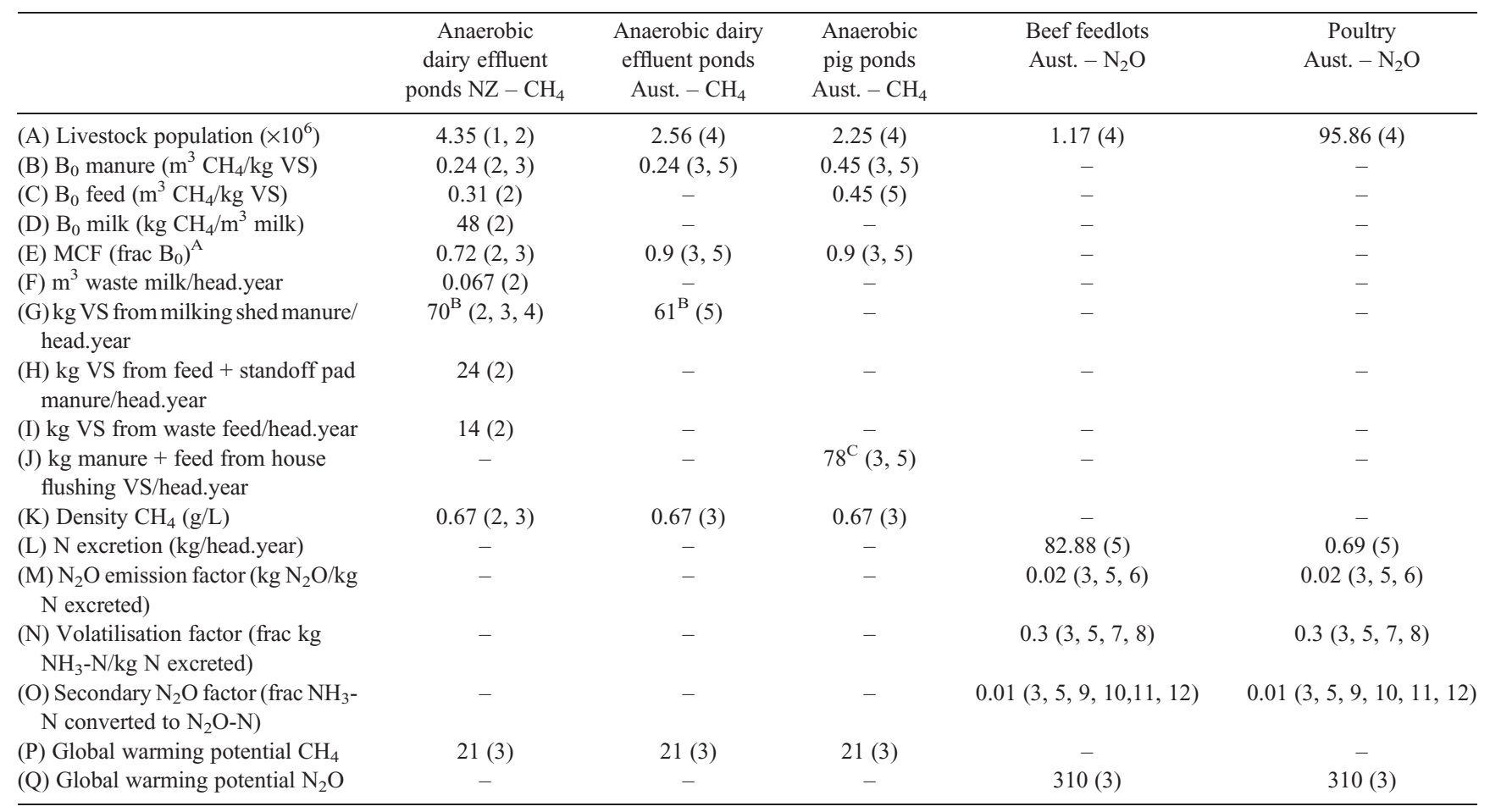

\footnotetext{
${ }^{\mathrm{A}}$ Methane conversion factors for 'lagoons' from Mangino et al. (2001) used in inventories.

${ }^{\mathrm{B}}$ Based on $6 \%$ of manure from milking shed entering ponds.

${ }^{\mathrm{C}}$ Back-calculated from inventory's VS excretion rates, $\mathrm{B}_{0}, \mathrm{MCF}$, population data and nationwide emission rate.
}

Table 2. Formulae used to calculate greenhouse gas (GHG) emissions from largest 'manure management' GHG sources in Australia and New Zealand (refer to Table 1 for symbols)

\begin{tabular}{|c|c|}
\hline GHG source & Emission calculation formulae \\
\hline $\begin{array}{l}\text { Anaerobic dairy effluent } \\
\text { ponds } \mathrm{NZ}-\mathrm{CH}_{4}\end{array}$ & $\begin{array}{l}\text { Nationwide emissions, } \mathrm{Mt} \mathrm{CO}_{2} \text {-e/year }(\mathrm{E})= \\
\qquad \begin{array}{l}\left.\sum \mathrm{A} \times \mathrm{G} \times \mathrm{B} \times \mathrm{E} \times \mathrm{K} / 1 \times 10^{\wedge 9} \times \mathrm{P}\right) \\
\left(\mathrm{A} \times \mathrm{H} \times \mathrm{B} \times \mathrm{E} \times \mathrm{K} / 1 \times 10^{\wedge 9} \times \mathrm{P}\right) \\
\left(\mathrm{A} \times \mathrm{I} \times \mathrm{C} \times \mathrm{E} \times \mathrm{K} / 1 \times 10^{\wedge 9} \times \mathrm{P}\right) \\
\left(\mathrm{A} \times \mathrm{F} \times \mathrm{D} / 1 \times 10^{\wedge 9} \times \mathrm{P}\right)\end{array}\end{array}$ \\
\hline $\begin{array}{l}\text { Anaerobic dairy effluent } \\
\text { ponds Aust. }-\mathrm{CH}_{4}\end{array}$ & $\mathrm{E}=\left(\mathrm{A} \times \mathrm{G} \times \mathrm{B} \times \mathrm{E} \times \mathrm{K} / 1 \times 10^{\wedge 9} \times \mathrm{P}\right)$ \\
\hline $\begin{array}{l}\text { Anaerobic pig ponds } \\
\text { Aust. }-\mathrm{CH}_{4}\end{array}$ & $\mathrm{E}=\left(\mathrm{A} \times \mathrm{J} \times \mathrm{B} \times \mathrm{E} \times \mathrm{K} / 1 \times 10^{\wedge 9} \times \mathrm{P}\right)$ \\
\hline $\begin{array}{l}\text { Beef feedlots and poultry } \\
\text { Aust. - direct } \mathrm{N}_{2} \mathrm{O}\end{array}$ & $\mathrm{E}=\left(\mathrm{A} \times \mathrm{L} \times \mathrm{M} / 1 \times 10^{\wedge 9} \times \mathrm{Q} \times 44 / 28\right)$ \\
\hline $\begin{array}{l}\text { Beef feedlots and poultry } \\
\text { Aust. - secondary } \mathrm{N}_{2} \mathrm{O}\end{array}$ & $\mathrm{E}=\left(\mathrm{A} \times \mathrm{L} \times \mathrm{N} \times \mathrm{O} / 1 \times 10^{\wedge 9} \times \mathrm{Q} \times 44 / 28\right)$ \\
\hline
\end{tabular}

(2004) upon which the NZ Inventory is based (Table 3). This is perhaps not surprising given the McGrath and Mason (2004) study employed a methodology that required an individual to stand beside a pond and not only manually count the $\mathrm{CH}_{4}$ bubbles but also to categorise their size.
The estimate by Chung et al. (2013) also incorporated the $\mathrm{CH}_{4}$-producing potential of wastes which enter ponds in addition to the milking shed manure. These include: manure from feed and standoff pads (i.e. hard surfaces used for providing supplementary feed and keeping cows off sodden pastures in wet periods); waste milk; and waste supplementary feed residues. It is significant to note that neither the NZ GHG Inventory nor indeed the generic international IPCC methodology make any account for these additional sources of waste that enter anaerobic ponds. While these wastes might have been assumed to have minor gas-emitting potential when the inventory was compiled, this is certainly not the case as evidence now shows that they can generate as much $\mathrm{CH}_{4}$ as the milking shed manure itself (Chung et al. 2013).

The use of feed and standoff pads is also a critical issue when quantifying pond $\mathrm{CH}_{4}$ emissions. Using survey data, Chung et al. (2013) estimated feed pad use is currently $20 \%$ across all NZ dairy farms. However, the rate of feed pad use is rapidly increasing and in some areas, is already nearing $100 \%$ (Northland Regional Council, pers. comm., 2012). Moreover, the Ministry for Agriculture and Forestry (pers. comm., 2012) stated that the use of feed, wintering, and stand-off pads will undoubtedly increase in coming years. In NZ, effluent from these pads is generally flushed into an anaerobic storage/ treatment system, thereby potentially boosting $\mathrm{CH}_{4}$ emissions 
Table 3. Relationship between inventory estimate of emissions and field-measured emission rates for various 'manure management' sources, calculated from published literature

\begin{tabular}{|c|c|c|c|c|}
\hline Author & Emission source & $\begin{array}{l}\text { Measurement technique/ } \\
\text { duration }\end{array}$ & $\begin{array}{c}\text { Emission factor (EF) } \\
\left(\mathrm{kg} \mathrm{CO}_{2} \text {-e/kg }\right. \\
\text { liveweight.year) }\end{array}$ & $\begin{array}{c}\text { EF given by national } \\
\text { inventory }\end{array}$ \\
\hline Williams (1993) & Dairy $\mathrm{CH}_{4}$ Aus. - ponds & Vented chamber/1 day during dry period & $0.66^{\mathrm{A}}$ & 0.52 \\
\hline Chung et al. (2013) & Dairy $\mathrm{CH}_{4} \mathrm{NZ}$ - ponds & Using IPCC inputs & $0.70^{\mathrm{B}}$ & 0.16 \\
\hline Craggs et al. (2008) & Dairy $\mathrm{CH}_{4} \mathrm{NZ}-$ ponds & Floating cover/1 year & $0.71^{\mathrm{C}}$ & 0.16 \\
\hline McGrath and Mason (2004) & Dairy $\mathrm{CH}_{4} \mathrm{NZ}$ - ponds & Observational bubble counting/ 3 months & $0.34^{\mathrm{D}}$ & 0.16 \\
\hline Maraseni and Maroulis (2008) & Pigs $\mathrm{CH}_{4}$ Aus. - ponds & Not described & $6.01^{\mathrm{E}}$ & 8.13 \\
\hline Craggs et al. (2008) & Pigs $\mathrm{CH}_{4} \mathrm{NZ}$ - ponds & Floating cover/1 year & $1.20^{\mathrm{F}}$ & 2.03 \\
\hline
\end{tabular}

${ }^{\mathrm{A}}$ Holstein-Friesian crossbreeds on farm, same as for national population (Dairy Australia 2013). No weight-adjustment applied in calculations.

${ }^{\mathrm{B}}$ Liveweights from NZ GHG Inventory used.

${ }^{\mathrm{C}}$ Breed on studied farm not reported, assumed same as national population. No weight-adjustment applied in calculations.

${ }^{\mathrm{D}}$ Breed on studied farm Friesian-dominated, average bodyweights similar (Piccand et al. 2013) to inventory estimate (460 kg/head), no weight-adjustment applied in calculations.

${ }^{\mathrm{E}}$ Weight-corrected for $53 \mathrm{~kg} / \mathrm{animal}$ for studied farm to $60 \mathrm{~kg} / \mathrm{head}$ for national population (Australian Government 2013).

${ }^{\mathrm{F}}$ Type of pigs not reported, no weight-adjustment applied in calculations.

by an order of several $\mathrm{Mt} \mathrm{CO}_{2}$-e/year. Without doubt, accurate and updated survey data on feed and standoff pad use across NZ are crucial from a GHG emission perspective. Yet this potentially large additional $\mathrm{CH}_{4}$ source is currently not considered by NZ's GHG Inventory, or indeed by IPCC methodology.

Similar to NZ, the main GHG emitted from manure on Australian dairy farms is $\mathrm{CH}_{4}$ generated from anaerobic effluent ponds. The Australian GHG Inventory estimates that $\sim 0.5 \mathrm{Mt} \mathrm{CO}_{2}$-e/year of $\mathrm{CH}_{4}$ are emitted from dairy effluent in Australia (Fig. 1): $\sim 0.4 \mathrm{Mt}$ from ponds, the other $0.1 \mathrm{Mt}$ coming from manure deposited directly on pastures (Australian Government 2013). The Australian Inventory purports that $6 \%$ of dairy cattle manure is deposited at the milking shed; the same as for NZ. However, information from the Victoria government (pers. comm., 2013) suggested that this value is more likely 15-20\%. Clearly, more survey data are needed to define this parameter as uncertainty in this one factor alone represents a potential error of $200-300 \%$ for the nationwide emission estimate.

One publication was identified reporting $\mathrm{CH}_{4}$ emissions from an Australian dairy effluent 'pond' (Williams 1993). Emissions from this 'pond', a waterlogged depression, were higher per $\mathrm{kg}$ liveweight than the Australian Inventory's estimate of effluent pond $\mathrm{CH}_{4}$ (Table 3). This higher emission rate could be attributable to farm-to-farm variations in animal genetics, feed regimes and environmental conditions. Importantly, it may also result from the omission of waste milk and feed in the Australian GHG Inventory's methodology. Chung et al. (2013) showed that waste milk, which enters ponds from pipe washdown and tank cleaning, could account for $\sim 25 \%$ of $\mathrm{CH}_{4}$ emissions from dairy farm effluent ponds.

Dairy Australia (2013) report that feed pad use is less than 2\% on Australian dairy farms. However, Gourley et al. (2007) noted that from the last decade, farming operations are intensifying so the trend to increased feedlot use is expected. Indeed, a continuing increase in feed pad use was confirmed by an industry representative (Department of Environment and Primary Industries, Victoria, pers. comm., 2013). This will have the potential to increase $\mathrm{CH}_{4}$ emissions from dairy effluent, with more manure being stored under anaerobic conditions, yet as for NZ, the additional wastes entering ponds from feed pads are not accounted for in the Australian GHG Inventory.

To summarise, the following significant concerns exist regarding dairy cattle emission estimates:

(1) The basis of the NZ Inventory has numerous problems including the validity of its source data (it also contain several key mathematical errors; refer to Fig. 1 for details).

(2) There are conflicting reports as to the amount of manure deposited at the milking shed with estimates from NZ and Australia that vary by $200-300 \%$.

(3) The impact of waste milk discharges and wasted feed that enters anaerobic ponds is currently overlooked and could represent a considerable $\mathrm{CH}_{4}$ source.

(4) While the dairy industry is moving towards far greater use of feed pads, the resultant increased manure load is currently unaccounted for by GHG inventories.

Further to the above issues pertaining to pond $\mathrm{CH}_{4}$ emissions, there also appear to be inconsistencies regarding $\mathrm{CH}_{4}$ emissions from pasture-deposited manure reported in the Australian and NZ GHG inventories (Australian Government 2013; New Zealand Government 2013). Emissions from this source are almost the same in both countries $\left(0.1 \mathrm{Mt} \mathrm{CO}_{2}\right.$-e/year). Although both countries have the same pasture disposal rate (94\%) NZ has almost twice as many dairy cows as Australia. Clearly there are serious questions over the accuracy of dairy effluent $\mathrm{CH}_{4}$ emissions for what is the largest GHG 'manure management' source for NZ and Australia combined.

\section{GHG emissions from pig 'manure management' (Australia)}

Methane is the main GHG produced on pig farms and is generated by the anaerobic degradation of effluent in ponds. The Australian GHG Inventory reports an annual $\mathrm{CH}_{4}$ production of $\sim 1 \mathrm{Mt} \mathrm{CO}_{2}$-e from pig effluent (Fig. 1) based on the input data and methodologies shown in Tables 1 and 2. 
The inventory's estimate of $\mathrm{CH}_{4}$ emissions is $\sim 8.13 \mathrm{~kg} \mathrm{CO}_{2}-\mathrm{e} / \mathrm{kg}$ liveweight.year. Maraseni and Maroulis (2008) reported a similar emission rate, $6.01 \mathrm{~kg} \mathrm{CO}$-e/kg liveweight.year, from the pond of a 15000 -head farm in Victoria (Table 3 ). This direct experimental evidence provides some verification that the national calculations are grounded in accurate $\mathrm{CH}_{4}$ emission factors. In addition to accurate emission factors, an understanding of the breakdown of pig 'manure management' practices in use across the country is essential because this can considerably affect nationwide GHG emissions. For the Australian pig industry, the inventory estimates that $\sim 80-90 \%$ of effluent is discharged to ponds and that the remaining fraction is managed via a combination of dry storage/litter techniques to which very low $\mathrm{CH}_{4}$ conversion factors $(5 \%$ of biochemical $\mathrm{CH}_{4}$ potential) are ascribed. By comparison Australia Pork Limited (APL, pers. comm., 2013) noted that $\sim 91 \%$ of pig effluent is treated in either conventional housing (where all effluent is managed in ponds) or a combination of conventional housing and deep litter (where some to all effluent is managed in ponds). The Australian Inventory's partitioning of 'manure management' systems on Australian pig farms is, thus, apparently based on sound 'manure management' data.

\section{GHG emissions from beef feedlots (Australia)}

Feedlots are commonly used for finishing beef cattle from pastures and croplands in Australia. The Australian GHG Inventory reports that $\sim 5 \%$ of Australia's beef cattle population [25-30 million, MLA (2013)] is on feedlots at any time (i.e. 1.17 million cattle) and that $\sim 0.95 \mathrm{Mt}$ of $\mathrm{CO}_{2}$-e/year as direct $\mathrm{N}_{2} \mathrm{O}$ is emitted from these feedlots (Fig. 1); almost onethird of total 'manure management' emissions. But are the emission factors which are used to calculate this estimate accurate? The direct $\mathrm{N}_{2} \mathrm{O}$ emission factor $\left(0.02 \mathrm{~kg} \mathrm{~N} \mathrm{~N}_{2} \mathrm{O} / \mathrm{kg} \mathrm{N}\right.$ excreted) represents the average outcome from complex biological mechanisms depending on ecological and environmental conditions, and was derived from IPCC expert judgement and research by Külling et al. (2003). Külling et al.'s (2003) study was conducted in Switzerland using dairy rather than beef cattle manure. Moreover, the key processes affecting the $\mathrm{N}_{2} \mathrm{O}$ emission factor, which include moisture (Montes et al. 2013), manure physical parameters (Chadwick 2005) and temperature (Dobbie and Smith 2001), are likely very different in Switzerland than Australia. For example, emissions from the manure in Külling et al.'s (2003) study were assessed at $20^{\circ} \mathrm{C}$. By contrast, temperatures on Australian beef feedlot surfaces of $45^{\circ} \mathrm{C}$ are common (Redding et al. in press) and can reach up to $60^{\circ} \mathrm{C}$ (Queensland Department of Agriculture, Fisheries and Forestry, pers. comm., 2013). Manure on feedlot surfaces is often cracked and moisture content varies considerably from the surface to the base, in contrast with the manure assessed by Külling et al. (2003), which was a wet slurry. In short, the vastly differing conditions of Külling et al.'s (2003) study compared with beef feedlots in Australia raise serious questions concerning the use of the northern hemisphere default factors in the Australian GHG Inventory.

Few published studies have verified the appropriateness of the above emission factors for Australia and no publications were identified reporting direct $\mathrm{N}_{2} \mathrm{O}$ emissions from beef feedlots in the country. Two studies conducted in the USA documented direct $\mathrm{N}_{2} \mathrm{O}$ measurements from beef cattle feedlots. Rahman et al. (2013), using a wind tunnel, reported an $\mathrm{N}_{2} \mathrm{O}$ emission rate of $4.67 \mathrm{~kg} \mathrm{CO}_{2}$-e/kg liveweight.year at a North Dakota feedlot, over four seasons. This rate is more than three times higher than the Australian GHG Inventory emission estimate (1.53 $\mathrm{kg} \mathrm{CO} \mathrm{CO}_{2}$-e/kg liveweight.year). By contrast, Borhan (2011), using flux chambers, reported $0.13 \mathrm{~kg}$ $\mathrm{CO}_{2}$-e/ $\mathrm{kg}$ liveweight.year (as direct $\mathrm{N}_{2} \mathrm{O}$ emissions) from a Texan beef feedlot over summer. The variability between these field measurements may have been due to differences in management practices, environmental conditions and measurement techniques. Rochette and Eriksen-Hamel (2008) noted that $\mathrm{N}_{2} \mathrm{O}$ measurements determined using chambers can yield highly variable results from site to site, and techniques applied influence the emission rate measured. Nonetheless, the emission fluxes reported from the two studies were not only markedly different from each other ( $\times 30$ difference); they also differed considerably variable from the Australian GHG Inventory estimate $(\times 3$ and $\times 12$ difference). This highlights the need for actual field measurements of direct $\mathrm{N}_{2} \mathrm{O}$ emissions from beef feedlots in Australia. Even a single field study, conducted over a sufficiently long period, could be used to develop a more appropriate emission factor than currently adopted for Australia. Without such measurements it is difficult to ascertain the appropriateness of the default emission factors currently used by the inventory. Consequently, the estimate of direct $\mathrm{N}_{2} \mathrm{O}$ emissions from Australian beef feedlots given in Fig. 1 remains unverified.

Secondary $\mathrm{N}_{2} \mathrm{O}$ emissions from beef feedlots in Australia have also been estimated using IPCC default factors from the 1995 Second Assessment Report. The $\mathrm{NH}_{3}$ volatilisation factor (0.3 $\mathrm{kg} \mathrm{NH}-\mathrm{N} / \mathrm{kg} \mathrm{N}$ excreted) used in Australia's GHG Inventory is sourced from publications by Hutchings et al. (2001), who focussed on Denmark's gas inventory and Rotz (2004), in their review on farm N management. Two Australian studies measured $\mathrm{NH}_{3}$ emissions from beef feedlots: Denmead et al. (2008) thus reported $66 \mathrm{~g} \mathrm{NH}_{3}-\mathrm{N} / \mathrm{kg}$ liveweight.year, while Loh et al. (2008) documented an average $108 \mathrm{~g} \mathrm{NH}_{3}-\mathrm{N} / \mathrm{kg}$ liveweight.year. Both studies used feedlots from Victoria and Queensland and employed open-path micrometeorological techniques to measure emissions. The $\mathrm{NH}_{3}$ fluxes reported are higher than the national GHG inventory estimate of $48 \mathrm{~g} \mathrm{NH}_{3}-\mathrm{N} /$ $\mathrm{kg}$ liveweight.year, which suggests that a nationally relevant $\mathrm{NH}_{3}$ volatilisation rate is more likely in the range of $0.4-0.7$ $\mathrm{kg} \mathrm{NH}_{3}-\mathrm{N} / \mathrm{kg} \mathrm{N}$ excreted. Further process work would be required to confirm this.

The secondary $\mathrm{N}_{2} \mathrm{O}$ emission factor $\left(0.01 \mathrm{~kg} \mathrm{~N}_{2} \mathrm{O}-\mathrm{N} / \mathrm{NH}_{3}-\mathrm{N}\right)$, adopted from the IPCC, is sourced from Butterbach-Bahl et al. (1997); Brumme et al. (1999); Denier van der Gon and Bleeker (2005); and Corre et al. (1999). These publications are all based on northern hemisphere studies. Butterbach-Bahl et al. (1997) and Brumme et al. (1999) determined secondary $\mathrm{N}_{2} \mathrm{O}$ emissions from German native forests, based on assumed atmospheric $\mathrm{N}$ deposition rates. Corre et al. (1999) did the same for various landuse types in Canada while Denier van der Gon and Bleeker (2005) determined secondary $\mathrm{N}_{2} \mathrm{O}$ emission factors for the Netherlands based on literature estimates of $\mathrm{N}$ deposition rates. Actual $\mathrm{N}$ deposition rates were not measured in any of these investigations. 
Moreover, the studies did not specifically examine the conversion of ammonia-deposited $\mathrm{N}$ to $\mathrm{N}_{2} \mathrm{O}$ from manure applications. Hence, as is the case with the direct $\mathrm{N}_{2} \mathrm{O}$ emission factors, the relevance of secondary $\mathrm{N}_{2} \mathrm{O}$ emission factors to agricultural systems in Australia is questionable.

In addition to unverified $\mathrm{N}_{2} \mathrm{O}$ emission factors, there is uncertainty regarding Australia's beef feedlot population. The Inventory's estimate of 1.17 million for 2011 differs from other sources: Muir et al. (2011) noted that $\sim 680000$ cattle are on Australia's feedlots at any time, while the industry itself reported a feedlot population of 788000 in June 2011 (ALFA 2013). These variations can affect Australia's beef feedlot manure GHG emission estimate by up to $100 \%$. Thus, it is crucial that the inventory adopts the most accurate population estimate, which should be that given by the industry.

Another important consideration in estimating beef feedlot manure GHG emissions is the practice of stockpiling (Fig. 2). Manure from feedlots can be cleaned-out regularly $(<1$ week) or as infrequently as $<6$ months (Dantzman et al. 1983) and is commonly stockpiled or composted before being applied to agricultural land (Queensland Department of Agriculture, Fisheries and Forestry staff, pers. comm., 2013). If feedlot manure is frequently removed, the corresponding GHG emissions will be low. However, emissions from the manure once it is applied to land may be high and will contribute to agricultural soils emissions (12 $\mathrm{Mt} \mathrm{CO}_{2}$-e/year for Australia). If manure is stockpiled or composted for a prolonged period, it could emit significant quantities of $\mathrm{N}_{2} \mathrm{O}, \mathrm{NH}_{3}$ and $\mathrm{CH}_{4}$ under suitable environmental conditions. For example, Pattey et al. (2005) demonstrated that $\mathrm{GHG}\left(\mathrm{N}_{2} \mathrm{O}\right.$ and $\mathrm{CH}_{4}$ combined) emissions from poorly managed beef manure compost can be seven times greater than from the same manure in well aerated composting piles; although additional secondary $\mathrm{N}_{2} \mathrm{O}$ emissions through $\mathrm{NH}_{3}$ volatilisation would need to be considered.

Emissions from stockpiled or composted manure are not quantified in the Australian GHG Inventory. Moreover, as no published field-measured emissions from manure stockpiling exist it is difficult to ascertain whether these storage systems are significant GHG sources. Work is needed to elucidate GHG emissions from stockpiled and composted beef feedlot manure in Australia.

\section{GHG emissions from poultry litter management (Australia)}

According to the Australian GHG Inventory, direct and secondary $\mathrm{N}_{2} \mathrm{O}$ emissions from poultry shed litter are responsible for $\sim 0.75 \mathrm{Mt} \mathrm{CO}_{2}$-e/year (Fig. 1). The input parameters used to calculate these $\mathrm{N}_{2} \mathrm{O}$ emissions are summarised in Tables 1 and 2. No published studies have reported $\mathrm{N}_{2} \mathrm{O}$ or $\mathrm{NH}_{3}$ fluxes from Australian poultry sheds. Robertson et al. (2002) recorded an average $\mathrm{NH}_{3}$ flux of 0.2 $\mathrm{kg} /$ head.year from a meat-poultry shed in the UK. Using the default emission factor of 0.01 for secondary $\mathrm{N}_{2} \mathrm{O}$ emissions (in lieu of more applicable data) this equates to $\sim 0.1 \mathrm{Mt} \mathrm{CO}_{2}$-e/year when transposed to Australia's national poultry population; similar to the Australian GHG Inventory's estimate of poultry secondary $\mathrm{N}_{2} \mathrm{O}$ emissions (Fig. 1). Yet, as was demonstrated in the beef 'manure management' discussion, published countryspecific data are required to validate the use of the northern hemisphere factors for predicting poultry manure $\mathrm{N}_{2} \mathrm{O}$ emissions because conditions in Australian poultry sheds could be very different from those in Europe. We are aware of work underway measuring $\mathrm{N}_{2} \mathrm{O}$ and $\mathrm{NH}_{3}$ emissions in poultry sheds across Australia. Data from this project, which is expected to be completed in mid-2015, will provide valuable insight into the accuracy of the emission factors currently adopted by the Australian GHG Inventory.

\section{Other sources}

The remaining 'manure management' GHG emission sources in Australia and NZ each produce less than $0.1 \mathrm{Mt} \mathrm{CO}_{2}$-e/year, according to the respective national Inventories. Some of these emission profiles are well developed, such as NZ's estimate for pig effluent pond $\mathrm{CH}_{4}$, which is based on emission factors verified by field measurements (Craggs et al. 2008) and recent manure management survey data (Hill 2012). Other sources, however, may emit greater quantities of GHG than currently estimated by inventory protocols. For example, secondary $\mathrm{N}_{2} \mathrm{O}$ emissions from dairy effluent ponds in NZ are not accounted for in the national GHG inventory. Yet, in a study by Pratt et al. (2012), measured $\mathrm{NH}_{3}$ emissions from an anaerobic dairy effluent pond indicated a nationwide secondary $\mathrm{N}_{2} \mathrm{O}$ production rate of $0.4 \mathrm{Mt} \mathrm{CO}_{2}$-e/year (using Table 1's secondary $\mathrm{N}_{2} \mathrm{O}$ emission
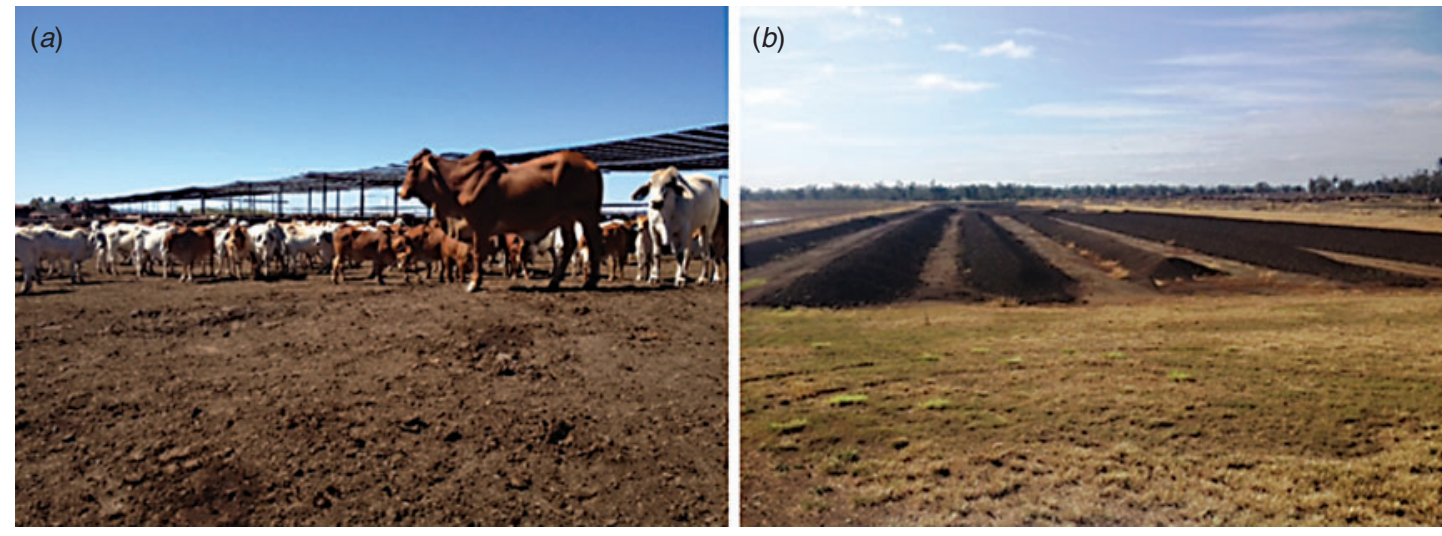

Fig. 2. Manure that is collected on beef feedlot surfaces $(a)$ is often removed regularly and either stockpiled or composted in windrows $(b)$ before being applied to land. 
factor). The accuracy of this estimate is compromised by the extremely short monitoring period ( 2 days) on a $4-\mathrm{m}^{2}$ section of one pond, and the questionable appropriateness of the secondary $\mathrm{N}_{2} \mathrm{O}$ emission factor. Nonetheless, the $\mathrm{NH}_{3}$ emissions reported on this pond warrant further field measurements in this area.

\section{GHG mitigation options and implications for research policy}

\section{Mitigation options across the sectors}

There are many practical options for mitigating $\mathrm{CH}_{4}$ emissions from dairy effluent ponds including those summarised in Table 4. In NZ, agriculture has been exempted from the country's emissions trading scheme and therefore there is a lack of incentive to implement any significant technology changes for the sake of addressing greenhouse gas emissions per se. However, the economics of these technologies are sensitive to volumetric loading rates (i.e. the amount of wastes anaerobically treated per unit of pond volume) and with research have significant potential to be further optimised. Furthermore, changes in management practice such the increase in the use of feed pads, and thus more collected manure, significantly increase the production of biogas; this can significantly improve the profitability of schemes such as $\mathrm{CH}_{4}$ recovery for energy (Shilton et al. 2009).

In Australia the principal manure GHG source is $\mathrm{CH}_{4}$ emissions from pig farms and the current estimate of these emissions appears to be well supported by industry data and field measurements. The potential for efficient energy recovery, and therefore $\mathrm{CH}_{4}$ mitigation, from pig ponds is typically greater than for dairy ponds due to their higher $\mathrm{CH}_{4}$ production rates. Several pig farms in Australia, and NZ, have deployed gas combustion systems on their effluent ponds, and the quantities of energy recovered have made this option economically viable (Fig. 3). This follows years of experience in viable energy recovery from livestock farms in Europe; Wilkinson (2011) reports $\sim 4000$ farm-scale digesters in Germany alone. In addition to energy recovery, Australia's Carbon Farming
Initiative - a federal government program which enables farmers and landowners from all farming industries to claim financial reward based on demonstrable GHG reductions entails further potential incentive for pig farmers to capture their effluent $\mathrm{CH}_{4}$ emissions (Maraseni and Maroulis 2008). Thus, there is the real possibility that emissions for this source could soon be greatly reduced.

Direct and secondary $\mathrm{N}_{2} \mathrm{O}$ emissions from beef feedlots and poultry sheds are the other major sources of 'manure management' GHG emissions in Australia. Strategies to

Table 4. Estimated efficiencies of anaerobic dairy effluent pond methane $\left(\mathrm{CH}_{4}\right)$ mitigation options (adapted from Shilton et al. 2009)

\begin{tabular}{|c|c|c|}
\hline Mitigation approach & $\begin{array}{l}\% \mathrm{CH}_{4} \\
\text { reduction } \\
\text { achievable }\end{array}$ & $\begin{array}{l}\text { Comments on confidence } \\
\text { in effectiveness } \\
\text { of technology }\end{array}$ \\
\hline $\begin{array}{l}\text { Cover pond and flaring/ } \\
\text { with or without energy } \\
\text { recovery }\end{array}$ & 97 & $\begin{array}{l}\text { Approach has been implemented } \\
\text { successfully on other livestock } \\
\text { farms (e.g. pig farms). } \\
\text { Effectiveness of flaring } \\
\text { required validation }\end{array}$ \\
\hline $\begin{array}{l}\text { Biofilter cover, comprising } \\
\text { methane-eating } \\
\text { bacteria, on pond } \\
\text { surface }\end{array}$ & 98 & $\begin{array}{l}\text { Biofilter cover design has not } \\
\text { been field tested. Percentage } \\
\mathrm{CH}_{4} \text { reduction shown is based } \\
\text { on preliminary study (Pratt } \\
\text { et al. 2013) }\end{array}$ \\
\hline $\begin{array}{l}\text { Conversion of anaerobic to } \\
\text { aerobic/facultative } \\
\text { ponds }\end{array}$ & 73 & $\begin{array}{l}\text { Easily achievable for farms, } \\
\text { which have } 2 \text {-pond treatment } \\
\text { systems (i.e. } \sim 40 \% \text { of } \mathrm{NZ} \\
\text { farms). } \% \mathrm{CH}_{4} \text { reduction based } \\
\text { on theoretical calculations, } \\
\text { field measurements required }\end{array}$ \\
\hline $\begin{array}{l}\text { Solids separation - i.e. } \\
\text { physically preventing } \\
\text { solids from entering } \\
\text { anaerobic ponds and } \\
\text { depositing them in } \\
\text { aerobic conditions on } \\
\text { pastures instead }\end{array}$ & 80 & $\begin{array}{l}\% \mathrm{CH}_{4} \text { reduction based on } \\
\text { theoretical calculations, field } \\
\text { measurements required }\end{array}$ \\
\hline
\end{tabular}

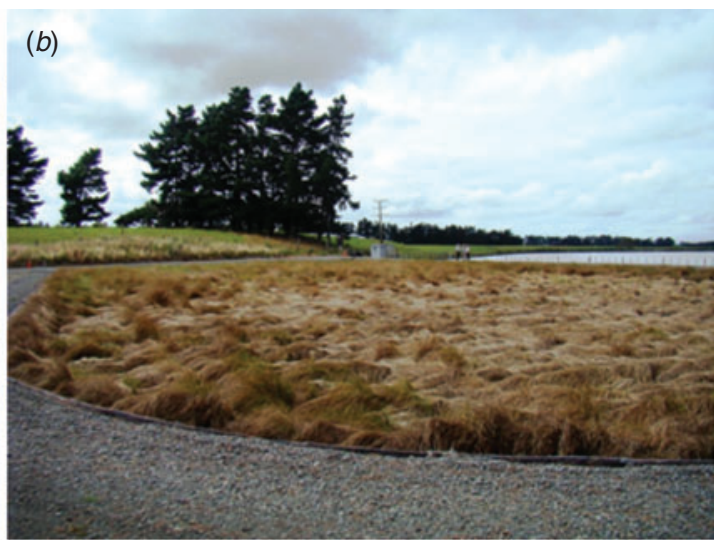

Fig. 3. Examples of methane $\left(\mathrm{CH}_{4}\right)$ mitigation options for effluent ponds $(a)$ a gas capture system on a piggery effluent pond in Australia; $(b)$ a biofilter for reducing nitrogen leaching on an industrial wastewater treatment pond in New Zealand. Research (Pratt et al. 2013) has shown that $\mathrm{CH}_{4}$-consuming bacteria could be embedded in the filter and achieve almost $95 \% \mathrm{CH}_{4}$ reductions from dairy ponds. 
mitigate these emissions may be implemented at the farmmanagement level. For example, de Klein et al. (2001) suggest tightening the supply of manure $\mathrm{N}$ to crops as a way to restrict direct and secondary $\mathrm{N}_{2} \mathrm{O}$ emissions. Reducing the amount of $\mathrm{N}$ excreted from livestock through dietary modifications could reduce gaseous emissions. Several researchers have shown that a decrease in excreted $\mathrm{N}$ decreases ammonia emissions, which would likely lead to reduced secondary $\mathrm{N}_{2} \mathrm{O}$ emissions (Canh et al. 1998; Hayes et al. 2004). However, research is needed to conclusively demonstrate a link between decreased $\mathrm{N}$ excretion rates and lower direct $\mathrm{N}_{2} \mathrm{O}$ emissions. In terms of technical mitigation options, the nitrification inhibitor dicyandiamide has been shown to reduce pastoral $\mathrm{N}_{2} \mathrm{O}$ emissions by $\sim 25 \%$ in NZ (Monaghan et al. 2013) and could conceivably be applied to mitigate feedlot direct $\mathrm{N}_{2} \mathrm{O}$ emissions. However, recent concerns have emerged regarding the detection of dicyandiamide in milk and its effects on animal and human health are unknown. Moreover, this compound is less effective in warm climates, so its efficiency in the Australian environment is likely suboptimal.

Options to reduce $\mathrm{NH}_{3}$ emissions (the precursor to secondary $\mathrm{N}_{2} \mathrm{O}$ ) from feed pads and poultry sheds include the use of sorbing materials, which could be incorporated into the manure management systems through direct application or by adding to the animals' feed. Such materials have been shown to be effective in preliminary trials (Redding 2011). Varel et al. (1999) showed that urease inhibitors can reduce $\mathrm{NH}_{3}$ emissions from feedlot cattle waste. It is also conceivable that appropriate management of vegetation around intensive farming systems (such as beef feedlots and poultry sheds) could reduce indirect $\mathrm{N}_{2} \mathrm{O}$ emissions via tighter cycling of $\mathrm{NH}_{3}$, which is volatilised from manures. Nonetheless, it should be borne in mind that discussing the wider potential strategies to mitigate $\mathrm{N}_{2} \mathrm{O}$ from Australian beef feedlots and poultry farms is premature given the uncertain emission estimates for these sources.
Policy implications of inaccurate estimates:

considerations in striving for best returns on research investment

Currently, no technologies are being widely deployed to mitigate 'manure management' GHG emissions in Australia or NZ. To some extent this can be attributed to the impression that enteric GHG emissions greatly overshadow manure emissions, given by inventories of beef-dominant countries. However, for countries with strong dairy and pig industries, such as Australia and NZ, this is not the case. The lack of emphasis on mitigating manure emissions can also be ascribed to the inaccurate and significant underreporting of emissions from these sources as discussed above. To illustrate this point we consider the following example regarding NZ's dairy farming industry where the dogma exists that effluent pond $\mathrm{CH}_{4}$ emissions are negligible compared with enteric emissions and, thus, no funding is directed to manure emission mitigation research. Table 5 shows recent literature values of maximum $\mathrm{CH}_{4}$ reduction possible from various enteric $\mathrm{CH}_{4}$ mitigation assessments.

The NZ Government recently invested $\sim \$ 50$ million for the next decade for research into agricultural GHG mitigation (NZAGRC 2012). Based on the breakdown of funding reported for 2011 (NZAGRC 2011), it appears that $\sim 35 \%$ (\$17 million) will be allocated to mitigating enteric $\mathrm{CH}_{4}$ emissions. By contrast, presently there is zero funding allocated to pond $\mathrm{CH}_{4}$ mitigation technologies. However, in terms of the 'state-of-readiness' of the technologies presented in Table 5, Eckard et al. (2010) noted that most enteric mitigation options are far from developed to the stage of being adopted. They comment that rumen manipulation technologies require much more research as vaccine use is controversial and enzymes have yet to show any sustained positive results. Patra (2012) remarked that most enteric mitigation strategies have not been tested in long-term experiments and, thus, require extensive future research. Although the magnitude of the costs

Table 5. Upper estimates of reductions in dairy (and other livestock) enteric methane $\left(\mathrm{CH}_{4}\right)$ emissions reported in the literature for a range of experimental mitigation approaches

\begin{tabular}{|c|c|c|c|c|}
\hline Reference & Mitigation approach & Description & Duration of study & $\begin{array}{l}\text { Maximum } \mathrm{CH}_{4} \\
\text { reduction (per cow, } \\
\text { unless otherwise stated) }\end{array}$ \\
\hline O’Neill et al. (2011) & Diet modification & Switched from grass to mixed ration diet & 10 weeks & $11 \%$ \\
\hline Monteny et al. (2006) & Diet modification & Switched from intensive to extensive grazing & 1 year & $21 \%$ \\
\hline $\begin{array}{l}\text { Beauchemin } \\
\text { and McGinn (2006) }\end{array}$ & Diet modification & Added oils and acids to diet & 6 months & $0 \%$ \\
\hline \multirow[t]{4}{*}{ Boadi et al. (2004) } & Diet modification & Improved feed quality intake & Based on review & $26 \%$ \\
\hline & Diet modification & Switched grazing forage & Based on review & $21 \%$ \\
\hline & Diet modification & Altered feeding regime & Based on review & $9 \%$ \\
\hline & Diet modification & Added palm kernel oil to feed & Based on review & $34 \%$ \\
\hline Grainger et al. (2008) & Rumen manipulation ${ }^{\mathrm{A}}$ & Added monesin & 5 months & $0 \%$ \\
\hline \multirow[t]{2}{*}{ Boadi et al. (2004) } & Rumen manipulation $^{\mathrm{A}}$ & Added bacteriosin & Based on review & $50 \%$ \\
\hline & Rumen manipulation ${ }^{\mathrm{A}}$ & General estimate on potential of vaccines & Based on review & $20 \%$ \\
\hline \multirow[t]{2}{*}{ Eckard et al. (2010) } & Rumen manipulation $^{\mathrm{A}}$ & Vaccine for sheep & Based on review & $8 \%$ \\
\hline & Selective breeding & General estimate & Based on review & $10-20 \%$ \\
\hline \multirow[t]{2}{*}{ Boadi et al. (2004) } & Selective breeding & NZ study & Based on review & $8-9 \%$ \\
\hline & Selective breeding & Canadian study & Based on review & $21 \%$ \\
\hline
\end{tabular}

${ }^{\mathrm{A}}$ Rumen manipulation targets the micro-fauna in livestock to reduce $\mathrm{CH}_{4}$ production. This is generally achieved by the injection of vaccines or enzymes, which inhibit methanogens in the rumen. 
Table 6. New Zealand dairy methane $\left(\mathrm{CH}_{4}\right)$ mitigation opportunities

\begin{tabular}{|c|c|c|}
\hline $\mathrm{CH}_{4}$ source & Enteric & $\begin{array}{l}\text { Anaerobic } \\
\text { ponds }\end{array}$ \\
\hline $\begin{array}{l}\text { Projected quantity of } \mathrm{CH}_{4} \\
\text { potentially mitigated } \\
\left(\mathrm{Gg} \mathrm{CO}_{2} \text {-e per decade }\right)\end{array}$ & 19700 & 13870 \\
\hline $\begin{array}{l}\text { Projected value of } \mathrm{CH}_{4} \\
\text { mitigation (\$ million/ } \\
\text { decade) })^{\mathrm{A}}\end{array}$ & $492^{\mathrm{B}}$ & $336^{\mathrm{C}}$ \\
\hline $\begin{array}{l}\text { Allocated research funding } \\
\text { over next } 10 \text { years } \\
\text { (\$ million) }\end{array}$ & 17 & 0 \\
\hline $\begin{array}{l}\text { Broad cost/benefit ratio of } \\
\text { research investment }\end{array}$ & 29 & No investment ${ }^{\mathrm{D}}$ \\
\hline State-of-readiness (risk) & $\begin{array}{c}\text { 'require many years } \\
\text { of research before } \\
\text { practical and commercially } \\
\text { viable products and } \\
\text { strategies are } \\
\text { available for use on farms' } \\
\text { Eckard et al. }(2010)\end{array}$ & $\begin{array}{l}\text { 'close to } \\
\text { market' } \\
\text { readiness }\end{array}$ \\
\hline
\end{tabular}

\footnotetext{
${ }^{\mathrm{A}}$ Based on $\mathrm{CO}_{2}$-e price of $\$ 25$ per tonne, does not factor in implementation costs.

${ }^{\mathrm{B}}$ Assumes 20\% reduction of emissions from enteric processes (through vaccines, diet manipulation or selective breeding).

${ }^{\mathrm{C}}$ Assumes $97 \%$ reduction for waste emissions (through covering ponds and burning the gas).

${ }^{\mathrm{D}}$ With $\$ 1$ million investment over next decade, becomes 336 (>10 times higher than for enteric emissions).
}

associated with enteric mitigation technologies is not yet known, it is likely that they will be significant. Eckard et al. (2010) stated that it will be many years before practical and commercially viable technologies are ready for use on farms. Some mitigation approaches may be used in combination to produce a cumulative effect in $\mathrm{CH}_{4}$ reduction. Even factoring in this 'combined effect' Eckard et al. (2010) noted that maximum $\mathrm{CH}_{4}$ reductions that could be achieved for pasturebased systems (through selective breeding and grazing management) would be just $20 \%$.

By contrast to enteric mitigation technologies, the 'state-ofreadiness' for pond $\mathrm{CH}_{4}$ mitigation strategies is high but further research is needed to optimise and practically demonstrate the technologies, as their uptake is currently low. The numbers in Table 6 show that, with a more balanced research portfolio, the NZ Government could achieve significant reductions in both enteric and pond $\mathrm{CH}_{4}$ emissions.

The case study on the current research investment portfolio for $\mathrm{NZ}$ dairy $\mathrm{CH}_{4}$ emissions has an important implication for the wider GHG 'manure management' category in Australia and NZ. It highlights the need to develop accurate emission profiles as a prerequisite to balance GHG mitigation research efforts to best-effect. In this respect, it is crucial to verify $\mathrm{N}_{2} \mathrm{O}$ emission estimates from beef feedlots and poultry farms in Australia because, based on current data, we simply do not know if these are significant agricultural GHG sources. This highlights the wider importance for countries to scrutinise all of their major GHG emission profiles, particularly if such assessments have not been made since the compilation of original inventories.

\section{Conclusions}

GHG emissions from livestock 'manure management' in Australia and $\mathrm{NZ}$ are more than $5 \mathrm{Mt} \mathrm{CO}_{2}$-e/year combined, according to best-available estimates. Methane from NZ and Australian dairy farms, $\mathrm{CH}_{4}$ from Australian pig farms and $\mathrm{N}_{2} \mathrm{O}$ from Australian beef feedlots and poultry sheds appear to be the major sources of livestock manure emissions. While the estimate of pig farm $\mathrm{CH}_{4}$ emissions appears reasonably accurate (based on industry data and field measurements), $\mathrm{CH}_{4}$ emission estimates from dairy farms are underestimated, and in particular increasing use of feed and standoff pads will lead to greater quantities of manure yielding $\mathrm{CH}_{4}$ from treatment/ storage under anaerobic conditions. Consequently, 'manure management' in these countries could be a much more significant $\mathrm{GHG}$ emission source than currently reported. The accuracy of $\mathrm{N}_{2} \mathrm{O}$ emission estimates from beef feedlots and poultry sheds in Australia remains uncertain because they are based entirely on northern hemisphere emission factors whose appropriateness for Australia is questionable and unverified. Therefore, most of Australasia's key livestock 'manure management' GHG emission profiles are apparently unsubstantiated. Encouragingly, there is a range of options available to mitigate manure GHG emissions. However, opportunities to mitigate emissions from the largest 'manure management' GHG source, i.e. dairy effluent pond $\mathrm{CH}_{4}$ in $\mathrm{NZ}$, are currently being missed due to imbalanced investment into mitigation research by the government, which stems from an underreporting of manure $\mathrm{CH}_{4}$ emissions by the NZ GHG Inventory. This is particularly alarming as this emission point source has several 'close-to-market' abatement solutions and therefore represents a real opportunity for meaningful action soon compared with the more difficult-to-implement, longterm alternative strategies that are currently being invested in. Internationally, this review demonstrates the critical importance for countries to re-scrutinise their GHG emission profiles, particularly if such assessments have not been made since the compilation of original inventories. Failure to act in this regard presents the very real risk of missing the 'low hanging fruit' in the rush to a meaningful response to climate change.

\section{Acknowledgements}

This research was funded by the Australian Government, University of Queensland, Meat and Livestock Australia, Australian Pork Limited, Rural Industries Research and Development Corporation and Australian Egg Corporation Limited as part of the National Agricultural Manure Management Program. Thanks to Alan Skerman, Ben Gilmour, Luke Boucher and Ray Murphy from the Queensland Department of Agriculture, Fisheries and Forestry, and staff from Australia Pork Limited and Victoria Department of Environment and Primary Industries for information. We are also grateful for the comments and advice of Janine Price and Ian Kruger in preparing the manuscript.

\section{References}

Akiyama H, Yagi K, Yan X (2005) Direct $\mathrm{N}_{2} \mathrm{O}$ emissions from rice paddy fields: summary of available data. Global Biogeochemical Cycles 19, GB1005. doi:10.1029/2004GB002378

ALFA (2013) Australian Lot Feeders' Association. Available at http://www. feedlots.com.au/ [Verified 23 July 2014] 
Australian Government (2013) 'Australian National Greenhouse Accounts National Inventory Report 2011. Volume 1.' (Australian Government: Canberra, ACT)

Beauchemin KA, McGinn SM (2006) Methane emissions from beef cattle: effects of fumaric acid, essential oil, and canola oil. Journal of Animal Science 84, 1489-1496.

Boadi D, Benchaar C, Chiquette J, Massé D (2004) Mitigation strategies to reduce enteric methane emissions from dairy cows: Update review. Canadian Journal of Animal Science 84, 319-335. doi:10.4141/A03-109

Borhan MS (2011) Greenhouse gas emissions from ground level area sources in dairy and cattle feedyard operations. Atmosphere (Toronto) 2, 303-329. doi:10.3390/atmos2030303

Bouwman AF, Boumans LJM, Batjes NH (2002a) Emissions of $\mathrm{N}_{2} \mathrm{O}$ and NO from fertilized fields: summary of available measurement data. Global Biogeochemical Cycles 16, 1058. doi:10.1029/2001GB00 1811

Bouwman AF, Boumans LJM, Batjes NH (2002b) Modeling global annual $\mathrm{N}_{2} \mathrm{O}$ and $\mathrm{NO}$ emissions from fertilized fields. Global Biogeochemical Cycles 16, 1080. doi:10.1029/2001GB001812

Brumme R, Borken W, Finke S (1999) Hierarchical control on nitrous oxide emission in forest ecosystems. Global Biogeochemical Cycles 13, 1137-1148. doi:10.1029/1999GB900017

Butterbach-Bahl K, Gasche R, Breuer L, Papen H (1997) Fluxes of NO and $\mathrm{N} 2 \mathrm{O}$ from temperate forest soils: impact of forest type, $\mathrm{N}$ deposition and of liming on the $\mathrm{NO}$ and $\mathrm{N} 2 \mathrm{O}$ emissions. Nutrient Cycling in Agroecosystems 48, 79-90. doi:10.1023/A:1009785521107

Canh TT, Aarnink AJA, Schutte JB, Sutton A, Langhout DJ, Verstegen MWA (1998) Dietary protein affects nitrogen excretion and ammonia emission from slurry of growing-finishing pigs. Livestock Production Science 56, 181-191. doi:10.1016/S0301-6226(98)00156-0

Chadwick DR (2005) Emissions of ammonia, nitrous oxide and methane from cattle manure heaps: effect of compaction and covering. Atmospheric Environment 39, 787-799. doi:10.1016/j.atmosenv.2004.10.012

Chung ML, Shilton AN, Guieysse B, Pratt C (2013) Questioning the accuracy of greenhouse gas accounting from agricultural waste: a case study. Journal of Environmental Quality 42, 654-659. doi:10.2134/jeq 2012.0350

Corre M, Pennock D, Kessel C, Kirkelliott D (1999) Estimation of annual nitrous oxide emissions from a transitional grassland-forest region in Saskatchewan, Canada. Biogeochemistry 44, 29-49. doi:10.1007/ BF00992997

Cottle DJ, Nolan JV, Wiedemann SG (2011) Ruminant enteric methane mitigation: a review. Animal Production Science 51, 491-514. doi:10. 1071/AN10163

Craggs R, Park J, Heubeck S (2008) Methane emissions from anaerobic ponds on a piggery and a dairy farm in New Zealand. Australian Journal of Experimental Agriculture 48, 142-146. doi:10.1071/EA07255

Dairy Australia (2013) Feeding systems used by Australian dairy farmers. Available at http://www.dairyaustralia.com.au/ /media/Documents/ Animals\%20feed\%20and\%20environment/Feed\%20and\%20nutrition/ Feeding\%20Systems $\% 20$ latest/Aus $\% 20$ five $\% 20$ main $\% 20$ feeding $\% 20$ systems.pdf [Verified 1 February 2014]

Dalal RC, Wang W, Robertson GP, Parton WJ (2003) Nitrous oxide emission from Australian agricultural lands and mitigation options: a review. Soil Research 41, 165-195. doi:10.1071/SR02064

Dantzman CL, Richter MF, Martin FG (1983) Chemical elements in soils under cattle pens. Journal of Environmental Quality 12, 164-168. doi:10. 2134/jeq1983.00472425001200020002x

de Klein CAM, Sherlock RR, Cameron KC, van der Weerden TJ (2001) Nitrous oxide emissions from agricultural soils in New Zealand - a review of current knowledge and directions for future research. Journal of the Royal Society of New Zealand 31, 543-574. doi:10.1080/03014223. 2001.9517667
Denier van der Gon H, Bleeker A (2005) Indirect N2O emission due to atmospheric N deposition for the Netherlands. Atmospheric Environment 39, 5827-5838. doi:10.1016/j.atmosenv.2005.06.019

Denmead OT, Chen D, Griffith DWT, Loh ZM, Bai M, Naylor T (2008) Emissions of the indirect greenhouse gases $\mathrm{NH} 3$ and $\mathrm{NOx}$ from Australian beef cattle feedlots. Australian Journal of Experimental Agriculture 48, 213-218. doi:10.1071/EA07276

Dobbie KE, Smith KA (2001) The effects of temperature, water-filled pore space and land use on $\mathrm{N} 2 \mathrm{O}$ emissions from an imperfectly drained gleysol. European Journal of Soil Science 52, 667-673. doi:10.1046/j.13652389.2001.00395.x

Eckard RJ, Grainger C, de Klein CAM (2010) Options for the abatement of methane and nitrous oxide from ruminant production: a review. Livestock Science 130, 47-56. doi:10.1016/j.livsci.2010.02.010

Gourley CJP, Powell JM, Dougherty WJ, Weaver DM (2007) Nutrient budgeting as an approach to improving nutrient management on Australian dairy farms. Australian Journal of Experimental Agriculture 47, 1064-1074. doi:10.1071/EA07017

Grainger C, Auldist MJ, Clarke T, Beauchemin KA, McGinn SM, Hannah MC, Eckard RJ, Lowe LB (2008) Use of monensin controlled-release capsules to reduce methane emissions and improve milk production of dairy cows offered pasture supplemented with grain. Journal of Dairy Science 91, 1159-1165. doi:10.3168/jds.2007-0319

Hayes ET, Leek ABG, Curran TP, Dodd VA, Carton OT, Beattie VE, O'Doherty JV (2004) The influence of diet crude protein level on odour and ammonia emissions from finishing pig houses. Bioresource Technology 91, 309-315. doi:10.1016/S0960-8524(03)00184-6

Hill J (2012) 'Recalculate pork industry emissions inventory.' (Massey University: Palmerston North, New Zealand)

Hutchings NJ, Sommer SG, Andersen JM, Asman WAH (2001) A detailed ammonia emission inventory for Denmark. Atmospheric Environment 35, 1959-1968. doi:10.1016/S1352-2310(00)00542-2

IPCC (2006) 'Emissions from livestock and manure management. IPCC guidelines for national greenhouse gas inventories. Vol. 4.' (IPCC: Kanegawa, Japan)

Külling DR, Menzi H, Sutter F, Lischer P, Kreuzer M (2003) Ammonia, nitrous oxide and methane emissions from differently stored dairy manure derived from grass- and hay-based rations. Nutrient Cycling in Agroecosystems 65, 13-22. doi:10.1023/A:1021857122265

Ledgard S, Brier G (2004) 'Estimation of the proportion of animal excreta transferred to the farm dairy effluent system.' (New Zealand Ministry for Agriculture and Forestry: Wellington, New Zealand)

Loh Z, Chen D, Bai M, Naylor T, Griffith D, Hill J, Denmead T, McGinn S, Edis R (2008) Measurement of greenhouse gas emissions from Australian feedlot beef production using open-path spectroscopy and atmospheric dispersion modelling. Australian Journal of Experimental Agriculture 48, 244-247. doi:10.1071/EA07244

Mangino J, Bartram D, Brazy A (2001) Development of a methane conversion factor to estimate emissions from animal waste lagoons. In 'US EPA's 17th annual emission inventory conference, Atlanta'.

Maraseni TN, Maroulis J (2008) Piggery: from environmental pollution to a climate change solution Journal of Environmental Science and Health. Part. B, Pesticides, Food Contaminants, and Agricultural Wastes 43, 358-363.

McGrath RJ, Mason IG (2004) An observational method for the assessment of biogas production from an anaerobic waste stabilisation pond treating farm dairy wastewater. Biosystems Engineering 87, 471-478. doi:10.1016/j.biosystemseng.2003.12.011

MLA (2013) 'MLA cattle.' Available at http://www.mla.com.au/About-thered-meat-industry/Industry-overview/Cattle [Verified 23 July 2014]

Monaghan RM, Smith LC, de Klein CAM (2013) The effectiveness of the nitrification inhibitor dicyandiamide (DCD) in reducing nitrate leaching and nitrous oxide emissions from a grazed winter forage crop in southern 
New Zealand. Agriculture, Ecosystems \& Environment 175, 29-38. doi:10.1016/j.agee.2013.04.019

Monteny G-J, Bannink A, Chadwick D (2006) Greenhouse gas abatement strategies for animal husbandry. Agriculture, Ecosystems \& Environment 112, 163-170. doi:10.1016/j.agee.2005.08.015

Montes F, Meinen R, Dell C, Rotz A, Hristov AN, Oh J, Waghorn G, Gerber PJ, Henderson B, Makkar HP, Dijkstra J (2013) Mitigation of methane and nitrous oxide emissions from animal operations: II. A review of manure management mitigation options Journal of Animal Science. doi:10.2527/jas.2013-6584

Muir SK, Chen D, Rowell D, Hill J (2011) Development and validation of a biophysical model of enteric methane emissions from Australian beef feedlots. In 'Modelling nutrient digestion and utilisation in farm animals'. (Eds D Sauvant, J Milgen, P Faverdin, N Friggens) pp. 412-420. (Wageningen Academic Publishers: Wageningen, The Netherlands)

NZAGRC (2011) New Zealand Agricultural Greenhouse Gas Research Centre (NZAGRC). Annual Report. Available at http://www.nzagrc. org.nz/annual-reports.html [Verified 23 July 2014]

NZAGRC (2012) New Zealand Agricultural Greenhouse Gas Research Centre (NZAGRC). Funding. Available at http://www.nzagrc.org.nz/ funding.html [Verified 23 July 2014]

New Zealand Government (2013) 'New Zealand's Greenhouse Gas Inventory 1990-2011.' (Ministry for the Environment: Wellington, New Zealand)

O'Neill BF, Deighton MH, O’Loughlin BM, Mulligan FJ, Boland TM, O'Donovan M, Lewis E (2011) Effects of a perennial ryegrass diet or total mixed ration diet offered to spring-calving Holstein-Friesian dairy cows on methane emissions, dry matter intake, and milk production. Journal of Dairy Science 94, 1941-1951. doi:10.3168/jds.2010-3361

Patra A (2012) Enteric methane mitigation technologies for ruminant livestock: a synthesis of current research and future directions. Environmental Monitoring and Assessment 184, 1929-1952. doi:10.10 07/s10661-011-2090-y

Pattey E, Trzcinski MK, Desjardins RL (2005) Quantifying the reduction of greenhouse gas emissions as a result of composting dairy and beef cattle manure. Nutrient Cycling in Agroecosystems 72, 173-187. doi:10.1007/ s10705-005-1268-5

Piccand V, Cutullic E, Meier S, Schori F, Kunz PL, Roche JR, Thomet P (2013) Production and reproduction of Fleckvieh, Brown Swiss, and 2 strains of Holstein-Friesian cows in a pasture-based, seasonal-calving dairy system. Journal of Dairy Science 96, 5352-5363. doi:10.3168/ jds.2012-6444

Pratt C, Walcroft AS, Tate KR, Ross DJ, Roy R, Reid MH, Veiga PW (2012) Biofiltration of methane emissions from a dairy farm effluent pond. Agriculture, Ecosystems \& Environment 152, 33-39. doi:10.1016/j. agee.2012.02.011
Pratt C, Deslippe J, Tate KR (2013) Testing a biofilter cover design to mitigate dairy effluent pond methane emissions. Environmental Science \& Technology 47, 526-532. doi:10.1021/es303225h

Rahman S, Borhan MS, Swanson K (2013) Greenhouse gas emissions from beef cattle pen surfaces in North Dakota. Environmental Technology 34, 1239-1246. doi:10.1080/09593330.2012.743598

Redding MR (2011) Bentonites and layered double hydroxides can decrease nutrient losses from spent poultry litter. Applied Clay Science 52, 20-26. doi:10.1016/j.clay.2011.01.016

Redding MR, Lewis RJ, Waller J, Phillips F, Griffith D in pressLargechamber methane and nitrous oxide measurements are comparable to the backward Lagrangian stochastic method. Journal of Environmental Quality, in press.

Robertson AP, Hoxey RP, Demmers TGM, Welch SK, Sneath RW, Stacey KF, Fothergill A, Filmer D, Fisher C (2002) Commercial-scale studies of the effect of broiler-protein intake on aerial pollutant emissions. Biosystems Engineering 82, 217-225. doi:10.1006/bioe.2002.0073

Rochette P, Eriksen-Hamel NS (2008) Chamber measurements of soil nitrous oxide flux: are absolute values reliable? Soil Science Society of America Journal 72, 331-342. doi:10.2136/sssaj2007.0215

Rotz CA (2004) Management to reduce nitrogen losses in animal production. Journal of Animal Science 82, E119-E137.

Saggar S, Bolan NS, Bhandral R, Hedley CB, Luo J (2004) A review of emissions of methane, ammonia, and nitrous oxide from animal excreta deposition and farm effluent application in grazed pastures. New Zealand Journal of Agricultural Research 47, 513-544. doi:10.1080/002882 33.2004 .9513618

Shilton AN, Guieysse B, Pratt C, Walcroft A (2009) GHG abatement: the new paradigm for wastewater management in the agricultural industry economic evaluation of options for a typical New Zealand dairy farm. In 'IWA Chemical Industries Specialist Group Conference'. (Water and Industry: Palmerston North, New Zealand)

Stehfest E, Bouwman L (2006) N2O and NO emission from agricultural fields and soils under natural vegetation: summarizing available measurement data and modeling of global annual emissions Nutrient Cycling in Agroecosystems 74, 207-228.

Varel VH, Nienaber JA, Freetly HC (1999) Conservation of nitrogen in cattle feedlot waste with urease inhibitors. Journal of Animal Science 77, $1162-1168$.

Wilkinson KG (2011) A comparison of the drivers influencing adoption of on-farm anaerobic digestion in Germany and Australia. Biomass and Bioenergy 35, 1613-1622. doi:10.1016/j.biombioe.2011.01.013

Williams DJ (1993) Methane emissions from manure of free-range dairy cows. Chemosphere 26, 179-187. doi:10.1016/0045-6535(93)90420-A 